\title{
Gizi Seimbang untuk Pencegahan Anemia
}

\author{
Purwati \\ E mail: watix_1006@yahoo.com \\ Prodi Kebidanan DIII, Fikes Universitas Muhammadiyah Purwokerto, Indonesia \\ Jl. Soepardjo Roestam Km. 7 Sokaraja, Banyumas \\ Telp/Fax. 6844252, 68344253
}

\begin{abstract}
Abstrak
Anemia dalam kehamilan merupakan salah satu masalah dikarenakan kekurangan sel darah merah selama kehamilan. Permasalahan mitra adalah 1) ibu hamil tidak datang di kelas ibu hamil, 2) tingginya angka ibu hamil dengan anemia sebanyak 5 dari 15 ibu hamil dan KEK 1 orang. Kegiatan IbM ini merupakan kerjasama antaran Prodi Kebidanan D3 khususnya bidang Komunitas dengan Bidan desa Karangtengah kecamatan Kembarang kabupaten Banyumas. Kegiatan ini dilaksanakan melalui kelas ibu hamil sebagai wadah untuk ibu hamil belajar tentang fisiologi dan ketidaknyaman kehamilan dan cara mengatasinya. Luaran yang diperoleh sesuai dengan perencanaan di awal yaitu : Aktifnya kembali kelas ibu hamil di PKD desa Karangtengah, meningkatnya pengetahuan ibu hamil tentang gizi seimbang dalam kehamilan, Adanya media pendidikan kesehatan tentang gizi seimbang di kelas ibu hamil PKD desa Karangtengah.
\end{abstract}

Kata Kunci: hamil; anemia.

\begin{abstract}
Anemia in pregnancy is a problem due to a lack of red blood cells during pregnancy. Partner problems are 1) pregnant women do not attend the class of pregnant women, 2) the high number of pregnant women with anemia is 5 out of 15 pregnant women and KEK 1 person. This IbM activity is a collaboration between the D3 Midwifery Study Program, especially in the Community sector with Midwives in Karangtengah village, Kembarang sub-district, Banyumas district. This activity is carried out through a pregnant woman class as a forum for pregnant women to learn about the physiology and discomfort of pregnancy and how to overcome them. The results obtained are in accordance with the initial planning, namely: the reactivation of the class of pregnant women in PKD Karangtengah village, increased knowledge of pregnant women about balanced nutrition in pregnancy, the existence of health education media about balanced nutrition in the PKD class of pregnant women in Karangtengah village.
\end{abstract}

Keywords: pregnant; anemia.

\section{Pendahuluan}

Anemia dalam kehamilan merupakan salah satu masalah dikarenakan kekurangan sel darah merah selama kehamilan. Hal ini dapat membahayakan ibu nhami dan janin yang dikandung, sehingga memerlukan penanganan yang serius dari berbagai pihak ${ }^{(1)}$. Berdasarkan Riskesdas (2013) prevalensi anemia pada ibu hamil masih tinggi yaitu sebesar $37,1 \%$ mengalami peningkatan dibandingkan Riskesdas (2010) sebesar $33,8 \%{ }^{(2)}$. Hasil studi pendahuluan didapatkan angka kejadian anemia pada ibu hamil di Kabupaten Banyumas dengan anemia pada tahun 2015 sebesar $55,37 \%$ dari seluruh ibu hamil yang periksa $\mathrm{Hb}^{(3)}$.

Upaya pencegahan anemia dalam kehamilan telah dilakukan selama bertahun-tahun melalui program pemberian 90 tablet $\mathrm{Fe}$ selama kehamilan. Menurut 
BKKBN (2009) pengetahuan ibu hamil tentang kesehatan khususnya anemia akan berpengaruh terhadap perilaku ibu hamil pada pelaksanaan program pencegahan anemia, sikap tersebut dapat berupa tanggapan (4). Selain itu penyuluhan, pendidikan kesehatan dan mengubah perilaku ibu hamil untuk selalu mengkonsumsi dan mendukung dengan mencukupi makan dengan gizi seimbang sangat diperlukan ${ }^{(1)}$. Kebutuhan nutrisi tersebut diperlukan oleh ibu hamil yaitu untuk Memenuhi kebutuhan gizi ibu dan janin, mencapai status gizi ibu hamil yang normal, untuk membangun jaringan tumbuh kembang janin dan ibu, mengatasi permasalahan selama kehamilan dan mendapatkan energi yang cukup selama kahmilan. .

Dengan adanya $\mathrm{IbM}$ tentang gizi seimbang menjadi sarana yang sesuai dalam mengatasi permasalahan pada mitra. Pada akhirnya diharapkan dapat membantu meningkatkan pemahaman dan ketrampilan ibu hamil dalam mengatasi masalah gizi pada ibu hamil sebagai salah satu upaya mencegah anemia. Berdasarkan analisis situasi diatas maka permasalahan mitra adalah 1) ibu hamil tidak datang di kelas ibu hamil, 2) tingginya angka ibu hamil dengan anemia sebanyak 5 dari 15 ibu hamil dan KEK 1 orang.

\section{Metode}

Kegiatan IbM ini merupakan kerjasama antaran Prodi Kebidanan D3 khususnya bidang Komunitas dengan Bidan desa Karangtengah kecamatan Kembarang kabupaten Banyumas. Kegiatan ini dilaksanakan melalui kelas ibu hamil sebagai wadah untuk ibu hamil belajar tentang fisiologi dan ketidaknyaman kehamilan dan cara mengatasinya. Kegiatan ini dilaksanakan dengan diawali sosialisasi pada ibu hamil, selanjutnya ibu hamil dilakukan pemeriksaan ANC dan di akhiri dengan pemberian pendidikan kesehatan baik secara bersamasama maupun secara indivu bagi ibu hamil yang mempunyai resiko tinggi serta ibu hamil yang terdetekdi nemi dan KEK. Target luaran dari kegiatan ini adalah aktifnya kembali kelas ibu hamil dan media pendidikan kesehatan berupa leaflet tentang gizi seimbang.

\section{Hasil dan Pembahasan}

Desa Karangtengah merupakan salah satu desa yang berada dibawah wilayah Puskesmas Kembaran II. Desa Karangtengah mempunyai 1 PKD dengan 1 Bidan desa, jumlah Posyandu terdiri dari 2 Posyandu dengan jumlah kader 10. Jumlah ibu hamil dari bulan November 2017 hingga Januari 2018 sebanyak 21 ibu hamil dan sudah melahirkan di bulan Desember 2017 sebanyak 6 ibu hamil. Saat ini Jumlah ibu hamil di desa Karangtengah berjumlah 15 orang terdiri dari 7 hamil fisiologis, 2 dengan resiko tinggi umur dan 1 orang menderita KEK dan 5 orang menderita Anemia. Program kelas ibu hamil di PKD Karangtengah berjalan 1 bulan sekali untuk mengedukasi ibu hamil sehingga tidak terjadi komplikasi dalam kehamilan, persalinan dan nifas

Kegiatan IbM di awali dengan koordinasi dengan bidan desa Karangtengah untuk mengundang ibu hamil pada tanggal 18 Januari 2018 di PKD Karangtengah. Kegiatan diawali dengan pendaftaran ibu hamil dan melakukan anamnesa pada ibu hamil. Selain itu ibu hamil diberi 
pertanyaan tentang pengetahuan gizi seimbang selama kehamilan.
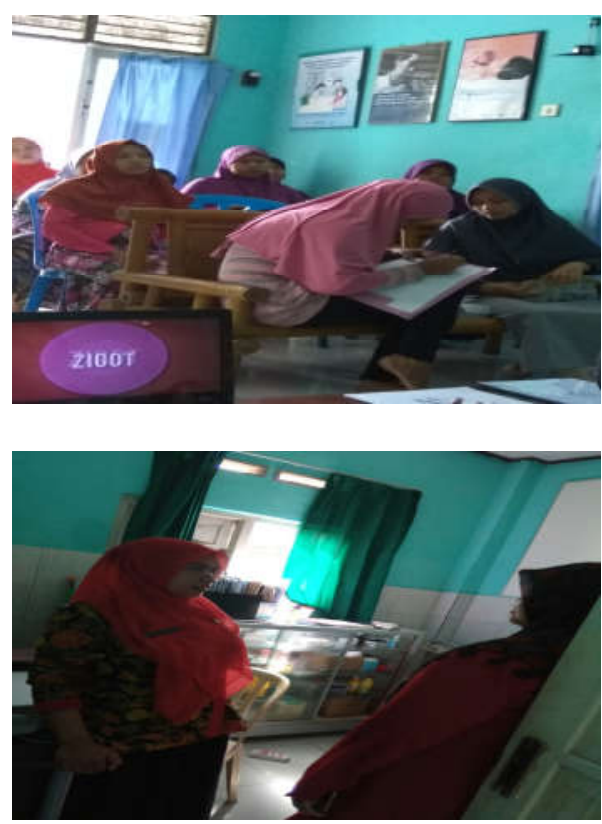

Hasil evaluasi dari pertanyaan awal pada ibu hamil yaitu dari 12 orang yang datang 7 orang menjawab 4 dari 10 pertanyaan dengan benar, 3 orang menjawab 6 pertanyaan dari 10 pertanyaan dan 2 orang menjawab 7 pertanyaan dari 10 pertanyaan. Hasil pemeriksaan ANC didapatkan 6 hamil normal, 4 hamil dengan anemia 1 dengan KEK dan 2 dengan resiko tinggi umur. Setelah dilakukan pemeriksaan ibu hamil diberi penddidikan kesehatan tentang gizi seimbang dalam kehamilan. Ibu hamil dengan anemia, KEK dan resiko tinggi diberikan informasi lebih mengenai resiko dari penyakit ikutannya, kemudian dilakukan pemantauan melalui kunjungan rumah dan anjuran untuk rutin periksa di PKD secara rutin. Di akhir kegiatan ibu hamil diberi pertanyaan kembali tentang gizi seimbang dalam kehamilan. Dengan hasil hampir semua ibu hamil dapat menjawab pertanyaan yang diberikan. Luaran yang diperoleh sesuai dengan perencanaan di awal yaitu :Aktifnya kembali kelas ibu hamil di PKD desa Karangtengah, meningkatnya pengetahuan ibu hamil tentang gizi seimbang dalam kehamilan, Adanya media pendidikan kesehatan tentang gizi seimbang di kelas ibu hamil PKD desa Karangtengah.

Faktor pendorong dan dalam kegiatan ini adalah membantu bidan desa dalam mengaktiflkan kembali kelas ibu hamil sebagai wadah untuk memberikan pengatehauan ibu hamil tentang kehamilan. Sedangkan hambatan dari kegiatan ini yaitu kurangnya kesadaran ibu hamil untuk menghadiri kelas ibu hamil merupakan faktor penghambat dalam kegiatan ini

\section{Kesimpulan}

Kelas ibu hamil di desa Karangtengah telah aktif kembali dengan kegiatan sesuai dengan program dari kelas ibu hamil. Kegiatan ini meingkatkan pengetahuan ibu hamil tentang gizi seimbang dalam kehamilan dan tersedianya media penunjang untuk melakukan pendidikan kesehatan yang dilakukan oleh bidan.

Diperlukan adanya dukungan tokoh masyarakat, agar kegiatan kelas ibu hamil dapat berjalan optimal. Kegiatan pendampingan ibu hamil dapat digunakan sebagai sarana komunikasi dan peningkatan pengetahuan, ketrampilan serta pendataan ibu hamil sekaligus deteksi dini tanda bahaya dalam kehamilan. 


\section{Daftar Pustaka}

[1] Manuaba. Sinopsis Obstetri.

[2] Kemenskes RI. Riskesdas 2013. Jakarta: Kementrian Kesehatan RI.

[3] Kementrian Kesehatan RI. Pedoman Umum Pengelolaan Posyandu. Jakarta, 2011.

[4] Kementrian Kesehatan RI. Buku Saku Posyandu. Jakarta: Pusat Promosi Kesehatan, 2012.

[5] Profil Kesehatan Kabupaten Banyumas. 2014.

[6] Putra. Baswara G.T. 2016. Gambaran Pengetahuan dan Kinerja Kader Posyandu di Wilayah Kerja UPT Puskesmas Mengwi I Kabupaten Badung pada Bulan Juli-Agustus 2015. E-Jurnal Medika. vol.5. no.10. Oktober 2016.

http://ojs.unud.ac.index.php 